\title{
Correction: The multiple sclerosis rating scale, revised (MSRS-R): Development, refinement, and psychometric validation using an online community
}

\author{
Paul Wicks ${ }^{*}$, Timothy E Vaughan and Michael P Massagli
}

\section{Correction}

In our study [1], we neglected to obtain formal permission to use the correct version of PRIMUS [2]. Therefore after publication we asked the Publisher to remove the results obtained with the PRIMUS tool and the data associated with it. Although amendments were included in the pdf version of the article by the Publisher, the website $\mathrm{xml}$ version was left unchanged. To remove confusion, please use the corrected pdf version of the article that can be downloaded here: http://www.hqlo. com/content/pdf/1477-7525-10-70.pdf.

The authors and the Publisher apologize to the readers and the owners of PRIMUS for the inconvenience caused.

Received: 8 April 2013 Accepted: 8 April 2013

Published: 12 April 2013

\section{References}

1. Wicks P, Vaughan TE, Massagli MP: The multiple sclerosis rating scale, revised (MSRS-R): Development, refinement, and psychometric validation using an online community. Health Qual Life Outcomes 2012, 10:70

2. Doward LC, McKenna SP, Meads DM, Twiss J, Eckert BJ: The development of patient-reported outcome indices for multiple sclerosis (PRIMUS). Mult Scler 2009, 15(9):1092-1102.

* Correspondence: pwicks@patientslikeme.com

PatientsLikeMe Inc, 155 Second Street, Cambridge, MA 02141, USA

Submit your next manuscript to BioMed Central and take full advantage of:

- Convenient online submission

- Thorough peer review

- No space constraints or color figure charges

- Immediate publication on acceptance

- Inclusion in PubMed, CAS, Scopus and Google Scholar

- Research which is freely available for redistribution 